\title{
Physical-chemical characterization of pre-cooked mixed rice flour and barley bagasse
}

\author{
Caracterização físico-química de farinha mista \\ pré-cozida de arroz e bagaço de cevada
}

\author{
Diego Palmiro Ramirez Ascheri ${ }^{1 *}$; Luis Henrique Cavalcante ${ }^{2}$; \\ José Luís Ramírez Ascheri³; Carlos Wanderlei Piler de Carvalho ${ }^{3}$
}

\begin{abstract}
The extrusion processing parameters, chemical composition and water content of the flour mixture may affect the structure of rice flour, leading to products with different rheological behavior and hygroscopicity. Therefore, this work aimed to study the rheological properties and water adsorption of mixed flours of broken rice and barley bagasse obtained by extrusion cooking. Samples were prepared from a mixture of grits/bagasse between 82/18 and 73/27 (w/w) with water content between 18.04 and $26.96 \%$, using a single screw extruder. The rheological properties of the extruded flour were determined by a rapid viscosity analyzer to evaluate the cooking profile of the pastes by observing the pasting temperature, maximum viscosity, breakdown and retrogradation. The adsorption process was performed by weighing the samples stored at temperatures of $25,30,35$ and $45{ }^{\circ} \mathrm{C}$ with water activity between 0.112 and 0.973 . The isotherms were fitted using the following mathematical models: Halsey, Oswin, Smith, GAB and Peleg. The extruded composite flours were characterized by their lack of initial viscosity. The pasting temperature $\left(40-67^{\circ} \mathrm{C}\right)$, maximum viscosity $(690-1146 \mathrm{cP})$, breakdown viscosity $(0-175 \mathrm{cP})$ and retrogradation $(613-1382 \mathrm{cP})$ were lower than for raw rice flour. The Peleg equation fitted well to the water adsorption data and can be used to represent the sigmoidal type II shape of the water adsorption isotherms for the extruded mixed flours from rice grits and barley bagasse.
\end{abstract}

Key words: Hordeum vulgare. Oryza sativa. Byproduct. Paste viscosity. Water adsorption isotherms.

\section{Resumo}

Os parâmetros do processo de extrusão, composição química e teor de água da mistura podem afetar a estrutura da farinha de arroz originando produtos com diferentes comportamentos reológicos e higroscópicos. Por isso, o presente trabalho teve por objetivo estudar as principais propriedades reológicas e de adsorção de água de farinhas mistas de quirera de arroz e bagaço de cevada obtidas por extrusão termoplástica. As amostras foram elaboradas a partir de uma mistura de arroz/bagaço entre $82 / 18$ e $73 / 27(\mathrm{~m} / \mathrm{m})$ e teor de água entre 18,04 e $26,96 \%$, utilizando-se uma extrusora de parafuso único. As propriedades reológicas das farinhas extrudadas foram determinadas por meio de um determinador rápido de viscosidade avaliando-se o perfil de cozimento das pastas pela observação da temperatura de empastamento, viscosidade máxima, quebra de viscosidade e tendência à retrogradação. $O$ processo de adsorção foi determinado utilizando-se o método gravimétrico estático em temperaturas de 25, 30, 35 e $45^{\circ} \mathrm{C}$ e atividades de água entre 0,112 e 0,973 . As isotermas foram ajustadas a modelos matemáticos de

${ }^{1}$ Prof., Universidade Estadual de Goiás, UEG, Anápolis, GO, Brasil. E-mail: ascheridpr@gmail.com

2 Bacharel em Química Industrial, UEG, Anápolis, GO, Brasil. E-mail: luishcavalcante@hotmail.com

${ }^{3}$ Pesquisadores, EMBRAPA Agroindústria de Alimentos, Guaratiba, RJ, Brasil. E-mail: jose.ascheri@embrapa.br; carlos.piler@ embrapa.br

* Author for correspondence 
Halsey, Oswin, Smith, GAB e Peleg. As farinhas mistas extrudadas se caracterizaram por não apresentar viscosidade inicial. A temperatura de empastamento $\left(40-67{ }^{\circ} \mathrm{C}\right)$, viscosidade máxima $(690-1146 \mathrm{cP})$, quebra de viscosidade $(0-175 \mathrm{cP})$ e tendência à retrogradação $(613-1382 \mathrm{cP})$ foram inferiores às da farinha de arroz crua. Os dados de adsorção de água foram bem ajustados pela equação de Peleg, podendo-se utilizar para representar as isotermas de adsorção de água de forma sigmoidal do tipo II das farinhas mistas extrudadas de quirera de arroz e bagaço de cevada.

Palavras-chave: Hordeum vulgare. Oryza sativa. Subproduto. Viscosidade de pasta. Isotermas de sorção.

\section{Introduction}

According to the Brazilian Institute of Geography and Statistics (IBGE, 2014), the Brazilian population was 190732694 habitants as of November 2010, and it is estimated that by 2025 , this population will reach 228 million. This increase in population will have immediate and inevitable consequences, such as requiring a proportional increase in food supply. The natural resources to maintain this population are limited, and only rational and efficient use can lead to the production of food in sufficient quantity and satisfactory quality to meet the growing needs of consumers.

Brazil is a country of great agricultural activity; therefore, it is one of the largest agroindustrial waste producers. Barley bagasse, a byproduct of the brewing industry, is rich in fiber with significant protein content, which is used to feed dairy and meat animals (VIEIRA; BRAZ, 2009). Broken rice is a byproduct of rice processing with the same average chemical composition as intact rice and is a rich source of starch (SILVA; ASCHERI, 2009).

According to Rostagno et al. (2005), broken rice is a high-quality product with protein and digestible energy levels similar to maize. Although it has lower fat content than maize, broken rice has a higher starch content. It can be used in diets for laying hens, pigs and dairy cattle (BUTOLO, 2002).

In the literature, there is little information on the use of barley bagasse as a food and much less as extruded products for human consumption. In this study, mixed flours of barley bagasse and broken rice were prepared and extruded, which could lead to the introduction of a new product in the market with certain advantages. The barley bagasse can provide fiber and protein, which broken rice would complement with carbohydrates. The obtained extruded flours would be considered as an ingredient for bakery goods.

Santos et al. (2008) developed cookies using wheat flour and barley bagasse. The authors reported that the residual barley flour showed unique characteristics such as water and oil holding capacity and emulsifying activity because of its fiber content. These features facilitated the preparation of cookies and positively influenced the sensory characteristics of the final product. Moreover, barley flour bagasse is a good-quality ingredient for enriching bakery products with considerable dietary fiber content, and its can be used as a substitute for wheat flour produced cookies with good acceptability, even compared to biscuits made with $100 \%$ wheat flour.

The thermoplastic extrusion process consists of a heat treatment at a high temperature for a short time (SANTOS et al., 2010). The basic principle of this process is to convert a solid material into a fluid by applying heat and mechanical shear, compressing it through a die. This process promotes the disruption of the granular structure of starch, denaturing and re-directing proteins to form a final product with modified physical characteristics and predetermined geometry. Moreover, thermoplastic extrusion can hydrate starches and proteins, achieve homogenization, and perform plasticizing modification of the texture of food by expanding the structure.

According to Guy (2001), under mild extrusion process conditions, there are no significant changes in fiber content; however, Ascheri et al. (2006a) 
found that high temperatures, high screw speeds and low moisture contents led to an increase in solubilization of certain dietary fiber sources. Souza and Leonel (2010) performed the extrusion of cassava starch and citrus pulp and found that the fiber content and the moisture content affected the paste properties of the extruded flours.

Cardoso et al. (2014) studied the rheological properties and water adsorption of an extruded flour mixture of barley bagasse and broken rice flour in the ratio of $82: 18$ (grits/rice) and found that the apparent paste viscosity profile behaved similarly to raw rice; i.e., it presented no initial viscosity and was characterized by low paste viscosity temperature, breakdown viscosity and setback viscosity. The mathematical sorption model of Peleg (1993) presented the best fit for predicting water adsorption isotherms at 25 to $45^{\circ} \mathrm{C}$ with water activity between 0.11 and 0.97 .

Due to the changes to the raw material imposed by the extrusion process, it is important to understand the rheological properties and water absorption. The rheological properties represent an important behavior that can be correlated with sensory parameters (FERREIRA et al., 2002). The water adsorption properties allow setting the limits of hydration and dehydration of the product to estimate the humidity changes under certain conditions of temperature and relative humidity and to establish the initial moisture level that would induce deterioration of the product (ASCHERI et al., 2006b).
As these properties depend on the variables of the extrusion process and food composition, this study aimed to study the main rheological properties and water adsorption of extruded flours of broken rice and barley bagasse.

\section{Materials and Methods}

Barley bagasse was donated by the Beverage of Americas Company (AmBev) (Annapolis, GO, Brazil) with an initial moisture content of $309 \%$ on a wet basis. The broken rice was purchased in a local shop in Rio de Janeiro (Brazil).

The excess of water in the barley bagasse was removed by using a hydraulic pressing MA-098 (Marconi, Piracicaba, Brazil) set to $10,000 \mathrm{kgf}$ $\mathrm{m}^{2}$. The water content left in the pressed bagasse was determined according to AOAC (2005) and removed using a MA-035 fan oven (Marconi, Piracicaba, Brazil) at $105{ }^{\circ} \mathrm{C}$ to approximately $6 \%$ dry basis, ground in a Wiley mill type MA-580 (Marconi, Piracicaba, Brazil), then manually sieved using a $300 \mu \mathrm{m}$ aperture sieve. The sieved barley flour (FBC) was then used for the extrusion process.

Broken rice with an initial water content of approximately $12 \%$ on a dry basis was ground in a QU-J roller mill (Brabender, Duisburg, Germany) into rice flour (FQA).

The experimental design was completely randomized with three replications. The treatments consisted of broken rice flour, barley bagasse and water in the proportions shown in Table 1.

Table 1. Broken rice flour (FQA), barley bagasse (FBC) and water quantities in treatments of the experimental design adopted to analyze the rheological properties of extruded mixed flours of barley bagasse and broken rice flour.

\begin{tabular}{cccccrrr}
\hline \multirow{2}{*}{ Treatment } & \multicolumn{3}{c}{ Treatment composition } & & \multicolumn{3}{c}{ Rheological properties } \\
\cline { 2 - 3 } \cline { 6 - 7 } & FQA $(\%)$ & FBC $(\%)$ & Water* & & Vmax $(\mathrm{cP})^{1}$ & BD $(\mathrm{cP})^{1}$ & \multicolumn{1}{c}{ SB $(\mathrm{cP})^{1}$} \\
\hline T1 & 81.96 & 18.04 & 18.81 & & $1120.0 \pm 13.2 \mathrm{a}$ & $70.0 \pm 10.0 \mathrm{~b}$ & $1189.0 \pm 22.5 \mathrm{~b}$ \\
T2 & 73.04 & 26.96 & 18.81 & & $1146.0 \pm 14.0 \mathrm{a}$ & $175.0 \pm 21.7 \mathrm{a}$ & $1382.0 \pm 16.5 \mathrm{a}$ \\
T3 & 81.96 & 18.04 & 21.19 & & $680.0 \pm 11.3 \mathrm{~b}$ & $0.0 \pm 0.0 \mathrm{c}$ & $401.0 \pm 29.5 \mathrm{c}$ \\
T4 & 73.04 & 26.96 & 21.19 & & $690 \pm 39.6 \mathrm{~b}$ & $5.0 \pm 6.1 \mathrm{c}$ & $613.0 \pm 4.4 \mathrm{~d}$ \\
\hline
\end{tabular}

* Grams of water per 100 g flour mixture. Vmax = maximum viscosity; BD = break down; SB = set back.

${ }^{1}$ Means followed by the same letter in the column do not differ by the Tukey test $(\mathrm{p}>0.05)$. 
Before the extrusion process, rice and barley bagasse flours were manually mixed according to the experimental design shown in Table 1. The amount of water added to the mixtures was calculated using the following formula (ASCHERI et al., 2006a):

$$
Q_{a}=m_{a}\left(\frac{U_{f}-U_{i}}{100-U_{f}}\right)
$$

where $\mathrm{Q}_{\mathrm{a}}=$ amount of water $(\mathrm{mL}), \mathrm{U}_{\mathrm{f}}=$ final water content (\%) (Table 1), $\mathrm{U}_{\mathrm{i}}=$ initial water content $(\%)$, and $\mathrm{m}_{\mathrm{a}}=$ sample mass $(\mathrm{g})$.

After homogenization, the samples were stored in plastic bags and refrigerated for $24 \mathrm{~h}$ to allow adequate distribution and absorption of water.

The extrusion process was performed using a lab size single extruder 19/20DN (Brabender, Duisburg, Germany) attached to a torque rheometer DCE 330 (Brabender, Duisburg, Germany), fitted with a 3:1 compression rate screw, round die of $3 \mathrm{~mm}$, running at $180 \mathrm{rpm}$, feed speed $24 \mathrm{rpm}$, corresponding to a feed rate of $5 \mathrm{~kg} \mathrm{~h}^{-1}$. The temperatures of heating zones 1, 2 and 3 were kept constant at 80, 100 and $152{ }^{\circ} \mathrm{C}$, respectively. The extruded material was manually cut into $30 \mathrm{~cm}$ long extrudates that were dried in a fan oven at $60{ }^{\circ} \mathrm{C}$ for $6 \mathrm{~h}$. The extrudates were then ground into flour (FME).

Water content, fat content, crude protein and ashes were determined in the FBC and FQA samples following the methodology of AOAC (2005). Crude fiber was determined by the method of Van de Kamer and Van Ginkel (1952). The starch and amylose contents of the rice flour were determined. Starch content was determined according to the Lane-Enyon method (CEREDA et al., 2004) by microwave acid digestion. The amylose content was determined by the colorimetric method by Martinez and Cuevas (1989), using an iodine solution/potassium iodide as indicator, and the complex formed was measured on a spectrophotometer model 432 (Fento Instruments Industry and Trade, Sao Paulo, Brazil) at $620 \mathrm{~nm}$. All analyses were performed in triplicate.
The rheological properties of FQA and FME were analyzed in a rapid visco-analyzer model 4 (RVA, Newport Scientific PTY LTD, Sydney, Australia). The reading was performed in sample suspensions (12\%), adjusted at $14 \%$ moisture on wet basis. The RVA was programmed as follows: $25{ }^{\circ} \mathrm{C}$ for $2 \mathrm{~min}$, heating from 25 to $95{ }^{\circ} \mathrm{C}$ at a rate of $14{ }^{\circ} \mathrm{C} \mathrm{min}^{-1}$, keeping the suspension at $95^{\circ} \mathrm{C}$ for $3 \mathrm{~min}$ and cooling to $25^{\circ} \mathrm{C}$ at a rate of $14{ }^{\circ} \mathrm{C} \mathrm{min}^{-1}$. The paste curves were analyzed considering the following parameters: pasting temperature (Te), maximum peak viscosity (Vmax), minimum viscosity (Vmin) at $95{ }^{\circ} \mathrm{C}$, breakdown viscosity $(\mathrm{BD}=\mathrm{Vmax}-\mathrm{Vmin})$, final viscosity (Vfin) and setback viscosity, also called retrogradation viscosity ( $\mathrm{SB}=$ Vfin-Vmin). The apparent viscosity was expressed in centipoise $(\mathrm{cP})$.

The adsorption process was measured using the static gravimetric method according to the COST 90 project, as modified by Ascheri et al. (2003). Saturated salt solutions were placed in glass jars dissectors (1 L capacity), which were hermetically sealed to generate different water activity values (Aw). These values were calculated using the equation shown in Table 2, at varied temperatures of $25,30,35$ and $45{ }^{\circ} \mathrm{C}$, obtaining water activity values between 0.112 and 0.973 .

The initial dry mass $\left(\mathrm{m}_{\mathrm{i}}\right.$, in $\left.\mathrm{kg}\right)$ was determined by placing $0.5 \mathrm{~g}$ of sample in $25 \mathrm{~mL}$ glass containers, that had been previously weighed. The containers were transferred to an oven at $75{ }^{\circ} \mathrm{C}$ for approximately $6 \mathrm{~h}$, in triplicate, according to the method of the American Association of Cereal Chemists (2005). The dried samples in those glass containers were placed without lids in a chamber with variable saturated solutions, then stored in an M035/5 oven (Marconi, São Paulo, Brazil) to control the temperature. The process was monitored by weighing the samples every $3 \mathrm{~h}$ or more, until a dynamic equilibrium was achieved between the relative humidity generated inside the chamber and the sample moisture content, i.e., until no further weight change $\left(\mathrm{m}_{\mathrm{e}}\right.$ in $\mathrm{kg}$ ) was detected by weighing in a semi-analytical balance BG 400 (Gehaka, São Paulo, Brazil) with an accuracy of $0.001 \mathrm{~g}$. 
Table 2. Linear regression and respective correlation coefficient $\left(\mathrm{R}^{2}\right)$ used for calculation of the water activity values $\left(\mathrm{A}_{\mathrm{w}}\right)$ obtained for saturated salt solutions at different temperatures.

\begin{tabular}{clrcc}
\hline \multirow{2}{*}{ Equation } & \multicolumn{3}{c}{ Salt } & \multicolumn{3}{c}{ Coefficients } \\
\cline { 3 - 5 } & $\mathrm{LiCl}$ & 72.634 & $\mathrm{k}_{2}$ & $\mathrm{R}^{2}$ \\
\hline & $\mathrm{KC}_{2} \mathrm{COOH}$ & 599.791 & 3.422 & 0.9557 \\
& $\mathrm{MgCl}_{2}$ & 277.202 & 2.506 & 0.9977 \\
& $\mathrm{KI}$ & 254.101 & 1.225 & 0.9870 \\
\multirow{2}{*}{$\operatorname{Ln}\left(\mathrm{A}_{\mathrm{w}}\right)=\frac{\mathrm{k}_{\mathrm{i}}}{\mathrm{T}}-\mathrm{k}_{1}$} & $\mathrm{NaCl}$ & 46.771 & 0.441 & 0.9998 \\
& $\left(\mathrm{NH}_{3}\right)_{2} \mathrm{SO}_{4}$ & 86.099 & 0.499 & 0.9977 \\
& $\mathrm{KCl}^{*}$ & 144.687 & 0.656 & 0.9998 \\
& $\mathrm{~K}_{2} \mathrm{SO}_{4}$ & 59.890 & 0.228 & 0.9995 \\
& &
\end{tabular}

$\mathrm{k}_{1}$ and $\mathrm{k}_{2}=$ angular and linear constant, respectively; $\mathrm{T}=$ absolute temperature (K). Source: Labuza et al. (1985).

The water content values at equilibrium in a percentage of one gram per $100 \mathrm{~g}$ dry matter $\left(\mathrm{X}_{\mathrm{e}}\right)$, at a certain adsorption time, were calculated according to Equation 1 (OLIVEIRA et al., 2011):

$$
\mathrm{X}_{\mathrm{e}}=100 \frac{\mathrm{m}_{\mathrm{e}}-\mathrm{m}_{\mathrm{i}}}{\mathrm{m}_{\mathrm{i}}}
$$

Statistical analysis was performed on the following results: maximum paste viscosity, viscosity breakdown and set-back viscosity or tendency to retrogradation. The average of three replicates was expressed as value \pm standard deviation. The data were subjected to analysis of variance, and the average values were compared by the Tukey test at $5 \%$ probability.
The mathematical models of two, three and four parameters for the water adsorption, shown in Table 3 , were applied to estimate the water content at equilibrium as a function of water activity.

The adjusted Equations 3-7 were compared by the $\mathrm{F}$ test by applying nonlinear regression at $5 \%$ probability (ELIAN, 1988), and statistics for the average relative error value (e) and standard error of estimate (SEE) were compared at the same level of prior probability. The regression analysis and statistics were performed with Statistica for Windows program version 8.0 of StatSoft (Tulsa, USA), $95 \%$ confidence.

Table 3. Water adsorption mathematical models used to predict the equilibrium water content $\left(\mathrm{X}_{\mathrm{e}}\right)$ of extruded mixed flours of barley bagasse and broken rice flour.

\begin{tabular}{llc}
\hline Model & Source & Equation \\
\hline Halsey & Chirife and Iglesias (1978) & $\mathrm{X}_{\mathrm{e}}=\left(\frac{-\mathrm{a}}{\ln \left(\mathrm{A}_{\mathrm{w}}\right)}\right)^{1 / \mathrm{b}}$ \\
Oswin & Chirife and Iglesias (1978) & $\mathrm{X}_{\mathrm{e}}=\mathrm{a}\left(\frac{\mathrm{A}_{\mathrm{w}}}{\left(1-\mathrm{A}_{\mathrm{w}}\right)}\right)^{\mathrm{b}}$ \\
Smith & LABUZA et al. (1985) & $\mathrm{X}_{\mathrm{e}}=\mathrm{a}-\mathrm{b} \ln \left(1-\mathrm{A}_{\mathrm{w}}\right)$ \\
GAB & Timmermann et al. (2001) & $\mathrm{X}_{\mathrm{e}}=\frac{\mathrm{abc} \mathrm{A}_{\mathrm{w}}}{\left(1-\mathrm{c} \mathrm{A}_{\mathrm{w}}\right)\left(1-\mathrm{c} \mathrm{A}_{\mathrm{w}}+\mathrm{bc} \mathrm{A}_{\mathrm{w}}\right)}(6)$ \\
Peleg & Peleg (1993) & $\mathrm{X}_{\mathrm{e}}=\mathrm{k}_{1} \mathrm{~A}_{\mathrm{w}}^{\mathrm{n}_{1}}+\mathrm{k}_{2} \mathrm{~A}_{\mathrm{w}}^{\mathrm{n} 2}$ \\
\hline
\end{tabular}

a, b, c, $\mathrm{k}_{1}, \mathrm{k}_{2}, \mathrm{n}_{1}, \mathrm{n}_{2}=$ coefficients; $\mathrm{A}_{\mathrm{w}}=$ water activity. 


\section{Results and Discussion}

The water content and dry matter of the compressed barley bagasse were 79.11 and $20.89 \%$, respectively. After drying and milling, the barley bagasse flour was constituted (Table 4), on a dry basis, of $5.68 \%$ moisture, $94.32 \%$ dry matter, $1.43 \%$ ash, $6.41 \%$ lipids, $15.21 \%$ protein and $18.15 \%$ crude fiber. These levels were within the range of values found in previous work with barley bagasse from the same industrial origin, as described in the work of Ascheri et al. (2005) and Santos et al. (2008), which were 1.2 and $3.1 \%$ ashes; 9.19 and 5.7\% lipids; 15.99 and $14.7 \%$ proteins and 17.38 and $18.4 \%$ crude fiber, respectively.

Table 4. Mean values and standard deviation (SD) of certain components of barley bagasse and broken rice flour*.

\begin{tabular}{lcc}
\hline & \multirow{2}{*}{ Components } & \multicolumn{2}{c}{ Mean \pm SD } \\
\cline { 2 - 3 } & Barley bagasse & Broken rice flour \\
\hline Water content & $5.68 \pm 0.23$ & $11.5 \pm 0.15$ \\
Dry matter & $94.32 \pm 0.23$ & $88.5 \pm 1.24$ \\
Ash & $1.43 \pm 0.25$ & $0.68 \pm 0.87$ \\
Ether extract & $6.41 \pm 0.65$ & $0.74 \pm 0.02$ \\
Protein & $15.21 \pm 1.24$ & $9.89 \pm 0.66$ \\
Fiber crude & $18.15 \pm 1.12$ & $0.62 \pm 0.23$ \\
Starch & - & $79.21 \pm 2.45$ \\
Amylose $^{* *}$ & - & $19.23 \pm 1.93$ \\
\hline
\end{tabular}

* Grams per $100 \mathrm{~g}$ dry matter

** Grams per $100 \mathrm{~g}$ starch.

- Not determined.

Table 4 also shows that the FQA presented dry matter within the range of 86.96 and $93.52 \%$, as reported by Generoso et al. (2008) and Junqueira et al. (2009), respectively. The contents of $0.68 \%$ ash, $0.74 \%$ lipids, $9.89 \%$ protein and $0.62 \%$ crude fiber were similar to the values reported by Junqueira et al. (2009), which were $0.87,0.73,9.11$ and $0.45 \%$, respectively.

The starch content found in broken rice was lower than the value reported by Pinkrová et al. (2003) in white rice, which ranged from 84.4 to $87.7 \%$, and the value reported in upland rice cultivars by Ascheri et al. (2010), which ranged from 90.61 to $94.26 \%$. The amylose content was within the range of values obtained by González et al. (2004), 18.0 to $26.7 \%$, but lower than the amylose content found by Noosuk et al. (2003) in commercial rice (39.48\%) and by Ascheri et al. (2010) in different cultivars in the highlands of the Brazilian Savannah (22-26\%).

Concerning the rheological properties, the FQA (Figure 1) showed the same rice flour viscosity profile found by Ascheri et al. (2006a), Cardoso et al. (2014), Sacchetti et al. (2004), Silva and Ascheri (2009) and Zhou et al. (2002). The starch granules contained in the broken rice began to swell from 6 min at $81^{\circ} \mathrm{C}$, leading to an increase in viscosity. The maximum viscosity of $1294 \mathrm{cP}$ was reached after 8 $\min$ at $95{ }^{\circ} \mathrm{C}$. The minimum viscosity of $1098 \mathrm{cP}$ occurred 10 min before the cooling cycle, providing a breaking viscosity of $196 \mathrm{cP}$. The phenomenon of retrogradation/recovering viscosity began in the early $90{ }^{\circ} \mathrm{C}$ range of the cooling cycle, and the viscosity increased until the end of the run, giving a final viscosity of $3863 \mathrm{cP}$ and registering a value of $2765 \mathrm{cP}$ as the retrogradation tendency. 
Figure 1. Viscosity profile of raw flour $\left(3 / 4 £^{3} / 4\right)$ and extruded broken rice flour as a function of barley bagasse concentration and water content of the mixture: ---TM-- 18.04 and $18.81 \%$; $\times-$-r- $\times-18.04$ and $21.19 \%$; $\times$ ×-S- $\times \times 26.96$ and $18.81 \%$; --Æ-- 26.96 and $21.19 \% .3 / 43 / 4$ Temperature profile.

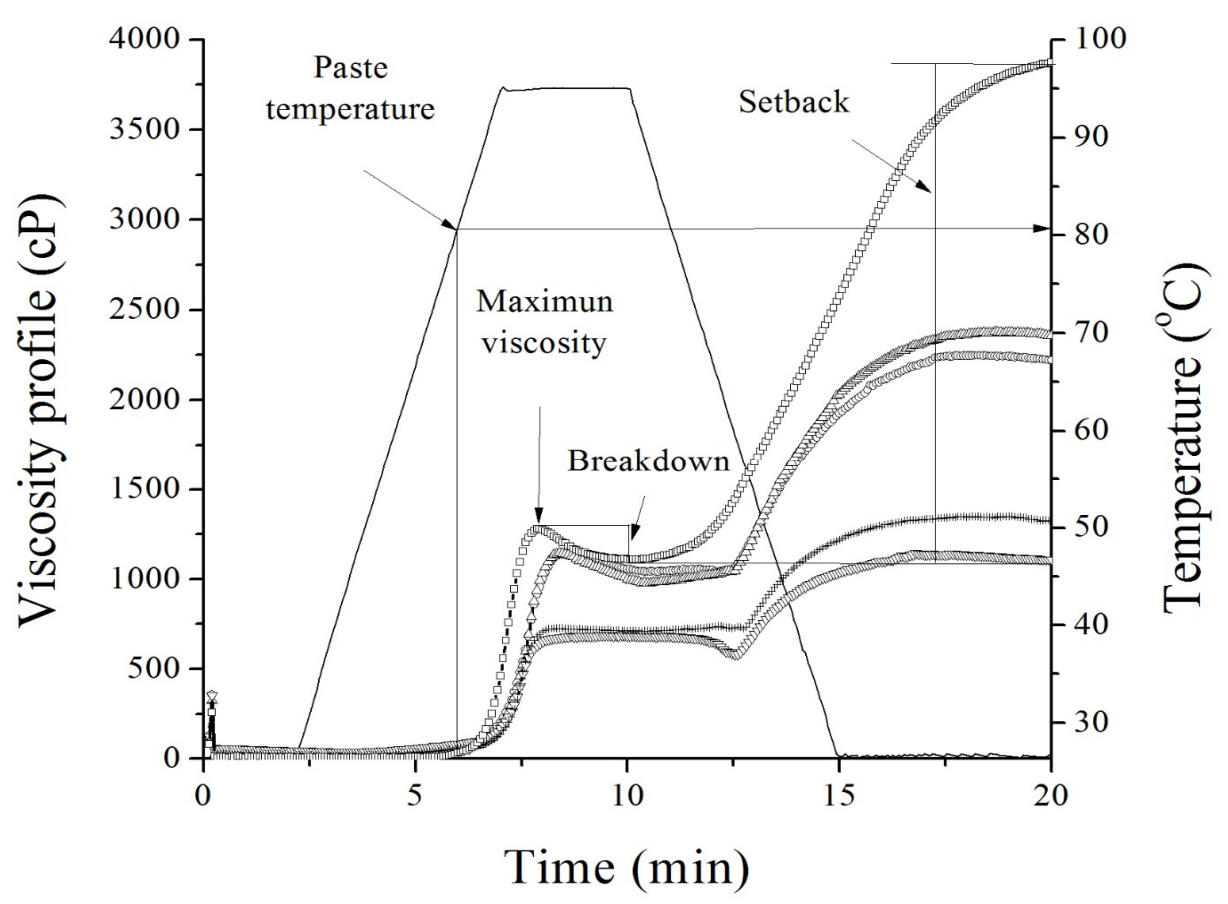

The viscosity profile of the extruded barley bagasse and rice flours in this work showed the same behavior as the samples studied by Cardoso et al. (2014), i.e., it presented no initial cold viscosity (Figure 1). This result was most likely due to the composition of the barley bagasse, which resulted in a reduction of the starchy material in the mixture, confirmed by Ascheri et al. (2006a), in extruded mixed flours of rice and jabuticaba bagasse. The absence of initial cold viscosity could be attributed to the extrusion process not causing sufficient mechanical damage to the starch granules in mixtures, disfavoring an increase in viscosity at this stage of the analysis. The cold viscosity is indicative of a high degree of mechanical shear that exposes chemical sites of great affinity for water, caused by the loss of starch granule integrity and internal crystallinity, similar to the findings of Marti et al. (2013), who studied the effect of the degree of cooking on rice using different types of processing, including thermoplastic extrusion.
However, Figure 1 reveals that the extruded mixed flours showed pasting temperature values: 40-67 ${ }^{\circ} \mathrm{C}$, maximum viscosity: 680-1146 cP, breakdown viscosity: $0-175 \mathrm{cP}$ and tendency to retrogradation: $401-1382 \mathrm{cP}$, lower than for the broken rice. These results indicate that the dilution of the starchy fraction by the addition of barley bagasse tends to reduce the paste viscosity readings, as described in the work of Wandee et al. (2014). These authors added increasing concentrations of grapefruit peel (Citrus maxima Merr.), leading to decreased viscosity readings. The authors attributed the reduction of the viscosity by the dilution of the starch fraction to gelatinization during the RVA readings, as well as the intrinsic characteristics of the non-amylaceous polysaccharide fraction present in the grapefruit peel. Fernandes et al. (2002) used extrusion to process soybean flour and corn grits. Ascheri et al. (2006a) processed rice and jabuticaba bagasse by extrusion and noted that the mix of flour influenced the gelation of the starchy fraction present in higher concentration in 
the rice. These authors also stated that the higher the proportion of non-starch material, the lower the availability of starch in the extruded melt capable of imposing resistance against the extruder motor, thus resulting in reduced mechanical stress and therefore shear on the processed material and lower molecular degradation (JONGSUTJARITTAM; CHAROENREIN, 2014).

The $\mathrm{F}$ test for the maximum viscosity results was 389.15 ( $p<0.01$ ), indicating differences between treatments. No significant differences between treatments $\mathrm{T} 1$ and $\mathrm{T} 2$ or between $\mathrm{T} 3$ and $\mathrm{T} 4$ were observed by the Tukey test (Table 1); however, T1 and $\mathrm{T} 2$ differed from T3 and T4, with a decrease of 1.6 times the value of Vmax. The same behavior was observed by Fernandes et al. (2002) and Ascheri et al. (2006a) in their studies.

Table 1 also shows significant differences between treatments applied to the variable breakdown viscosity $(\mathrm{F}=131.5, \mathrm{p}<0.01)$ and a tendency to retrogradation $(\mathrm{F}=1548.2, \mathrm{p}<0.01)$. $\mathrm{T} 1$ and $\mathrm{T} 2$ differed from each other, but $\mathrm{T} 1$ did not differ from $\mathrm{T} 3$ and $\mathrm{T} 4$, and the latter treatments did not differ from each other. T2 showed a higher breakdown viscosity $(175.0 \mathrm{cP})$ because the starch granules contained in the grits offered less resistance to hot stirring. Somehow, the presence of a higher amount of FBC (26.96\%) with $18.81 \%$ water in formulation T2 contributed to increased starch swelling, most likely due to the greater mechanical resistance of this formulation against the cylinder walls and screw, increasing the heating of the extrusion process and resulting in higher Vmax, BD and SB.

Figure 2 shows that the time required to reach equilibrium at water activities between 0.112 and 0.840 was from 3 to $27 \mathrm{~min}$. However, the time was increased for water activities above 0.96, ranging from 17 to $72 \mathrm{~min}$. Kulchan et al. (2010) reported that at high water activities, mass transfer occurs slowly, making it difficult to achieve equilibrium for water activity values above 0.9 .

The adsorption properties of starchy products are related to the availability of free hydroxyl groups (ASCHERI et al., 2010). During the extrusion process, high temperature, mechanical shear and limited water content promote starch breakdown, resulting in disruption of the molecular order and causing irreversible changes in their properties, making them soluble in cold water and increasing the availability of hygroscopic $\mathrm{OH}$ - groups, which interact with water through hydrogen bonding. Figure 3 shows the variation in the amount of water adsorbed by the composite extruded flour as a function of water activity.

Regardless of the effects of extrusion parameters, the equilibrium water content increased as a function of water activity (Figure 3). Al-Muhtaseb et al. (2004) reported that for a water activity value of 0.3 , water adsorption occurs in the amorphous region of starch granules, and at higher water activities, water adsorption can also occur in the crystalline region. In this study, it was observed that at different temperatures and for water activity equal to 0.3 , FME adsorbed between 5.2 and $7.9 \%$ of water, compatible with the values obtained by Lima et al. (2012) in the adsorption isotherm of uncooked rice flour and pre-gelatinized flours (between 5.3 and $8.3 \%$ at $30{ }^{\circ} \mathrm{C}$ ).

The isotherms of Figure 3 presented a sigmoidal form of type II, according to the classification of the International Union of Pure and Applied Chemistry (1985), typical of hydrophilic surfaces, such as pregelatinized rice flour by thermoplastic extrusion (ASCHERI; NASCIMENTO; ASCHERI, 2003), tomato powder (GOULA et al., 2008), extruded flour mixtures of starch-protein (WŁODARCZYKSTASIAK; JAMROZ, 2008), and starch of the rhizomes of swamp lily (ASCHERI et al., 2009), among others. 
Figure 2. Water content variation $\left(\mathrm{X}_{\mathrm{e}}\right)$ of flour mixtures of extruded broken rice and barley bagasse (FBC- barley bagasse concentration; TA - water content) as a function of adsorption time, obtained at different temperatures and water activities: 0.111-0.113 (£); 0.198-0.225 ( $\left.{ }^{\mathrm{TM}}\right)$; 0.310-0.328 (r); 0.653-0.689 (s); 0.745-0.753 (־); 0.795-0.810 (ó); 0.818-0.843(à), and 0.961-0.973(+).
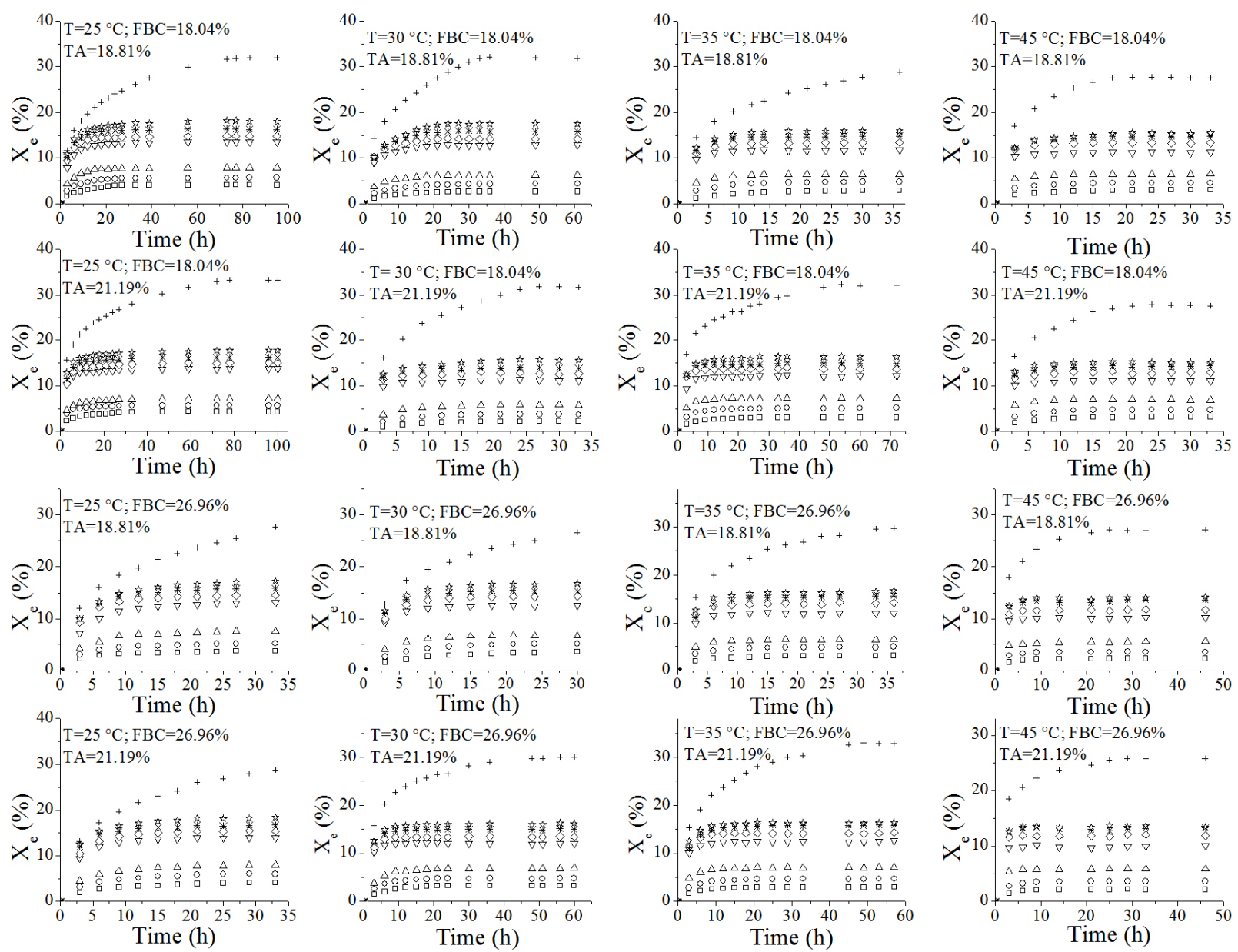
Figure 3. Equilibrium water content $\left(X_{e}\right)$ variation as a function of the water activity of the mixed flour of barley bagasse and rice grits obtained by extrusion, varying the percentage of bagasse and water content in the mixture: a) 18.04 and $18.81 \%$, B) 18.04 and $21.19 \%$ C) 26.96 and $18.81 \%$, D) 26.96 and $21.19 \%$. The Peleg model was fitted to the values of $X_{e}$.
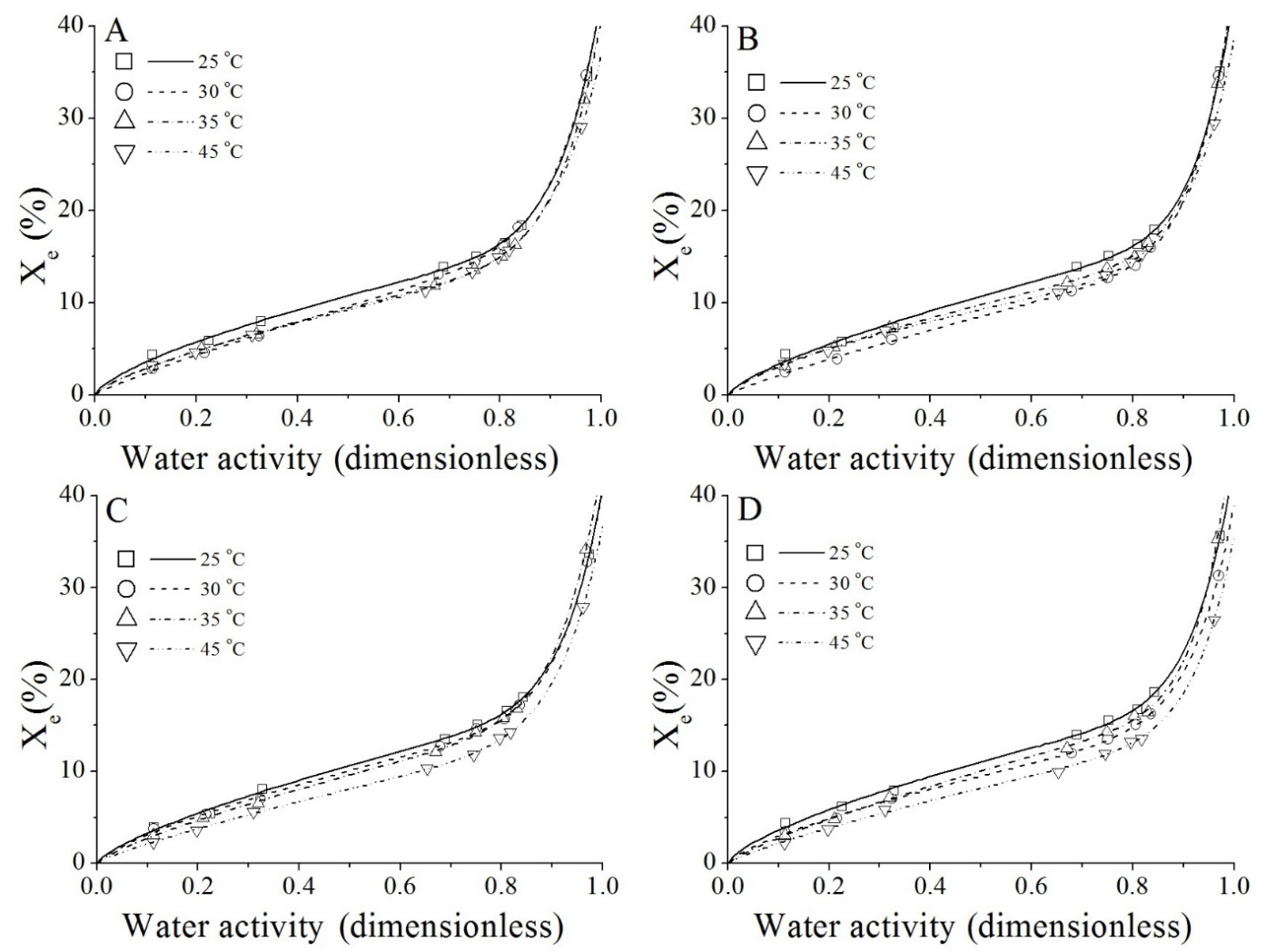

The $\mathrm{F}$ test in Table 5 shows that the nonlinear regression significantly contributed to the adjustment of the mathematical models applied to the adsorption isotherms of the studied flours. The reliability of adequacy was high in all isotherms, with greater than a $99.0 \%$ confidence level (p-value $<0.01)$. Although the values of EPE were low, the e values of the Halsey model were higher than expected (between 11 and 24\%), making it unsatisfactory for prediction of the isotherms under the studied conditions; these values should be less than $10 \%$, as established by Lomauro et al. (1985). However, it seems that the other models used, except the Oswin model for treatments 1 and 4 and Smith for treatment 2 , better fit the isotherms for values of e between 0.5 and $10 \%$ and EPE values below $1.0 \%$. The Peleg model showed values of e and EPE much

smaller than the other models applied, indicating that it is the most appropriate model to estimate the equilibrium water content of the extruded flours at different water activities and studied temperatures, which confirmed the results found by Cardoso et al. (2014).

With the isotherms modeled using the mathematical model Peleg, it could be seen that after obtaining the flour by extrusion cooking, the storage of this type of flour should be designed to limit moisture absorption, which would cause the proliferation of microorganisms. According to these isotherms (Figure 3), to maintain a low moisture content $(10 \%$, bs), the relative humidity of the storage environment should not be greater than $60 \%$, which is the recommended limit for water activity of dehydrated products according to Padula, 
as quoted by Sarantopoulos and Oliveira (2001). According to later authors, the removal of water until water activity levels reach 0.60 eliminates the possibility of the growth of microorganisms and reduces the activities of food spoilage reactions (FERREIRA NETO et al., 2005). In this study, these storage conditions coincide with the isotherms obtained at $30^{\circ} \mathrm{C}$.

Table 5. Minimum and maximum values of the F test, mean relative error (e) and standard error of estimate (SEE) obtained for the adequacy of mathematical models to the data on the water adsorption of four mixed extruded broken rice and barley bagasse flours held at different temperatures and water activities.

\begin{tabular}{ccccc}
\hline Model & Treatment & $\mathrm{F}^{*}$ & $\mathrm{e}$ & EPE \\
\hline \multirow{5}{*}{ Halsey } & $\mathrm{T}_{1}$ & $343.6-766.1$ & $11.9-23.8$ & $1.2-1.8$ \\
& $\mathrm{~T}_{2}$ & $657.0-875.9$ & $12.0-18.6$ & $1.0-1.3$ \\
& $\mathrm{~T}_{3}$ & $440.8-639.7$ & $14.8-20.9$ & $1.3-1.6$ \\
& $\mathrm{~T}_{4}$ & $417.7-700.6$ & $12.7-20.7$ & $1.3-1.3$ \\
Oswin & $\mathrm{T}_{1}$ & $1352.9-6706.1$ & $3.9-11.8$ & $0.4-0.9$ \\
& $\mathrm{~T}_{2}$ & $3925.4-6776.7$ & $3.9-7.7$ & $0.4-0.5$ \\
& $\mathrm{~T}_{3}$ & $2123.7-6062.3$ & $5.0-9.1$ & $0.4-0.7$ \\
& $\mathrm{~T}_{4}$ & $1848.5-6132.4$ & $4.0-10.5$ & $0.4-0.6$ \\
Smith & $\mathrm{T}_{1}$ & $1237.2-2775.0$ & $4.9-6.8$ & $0.6-0.9$ \\
& $\mathrm{~T}_{2}$ & $485.8-1585.1$ & $4.7-11.4$ & $0.9-1.4$ \\
& $\mathrm{~T}_{3}$ & $1113.0-2228.5$ & $4.9-7.0$ & $0.7-1.0$ \\
& $\mathrm{~T}_{4}$ & $609.6-1750.2$ & $5.2-8.4$ & $0.7-1.3$ \\
GAB & $\mathrm{T}_{1}$ & $869.8-1744.9$ & $4.7-6.7$ & $0.6-0.9$ \\
& $\mathrm{~T}_{2}$ & $607.5-911.0$ & $5.3-9.2$ & $0.8-1.1$ \\
& $\mathrm{~T}_{3}$ & $755.0-1303.5$ & $5.6-6.9$ & $0.6-1.0$ \\
& $\mathrm{~T}_{4}$ & $605.1-978.0$ & $6.2-8.3$ & $0.7-1.1$ \\
& $\mathrm{~T}_{1}$ & $3845.2-41865.0$ & $0.8-3.2$ & $0.1-0.4$ \\
& $\mathrm{~T}_{2}$ & $1845.4-15646.1$ & $1.2-4.5$ & $0.2-0.6$ \\
& $\mathrm{~T}_{3}$ & $4621.4-11362.9$ & $1.4-2.9$ & $0.2-0.3$ \\
& $\mathrm{~T}_{4}$ & $3888.4-13038.3$ & $1.7-2.9$ & $0.2-0.4$ \\
\hline
\end{tabular}

* At $1 \%$ significance.

\section{Conclusion}

According to the chemical composition results, the proteins and fibers of the barley bagasse and the proteins and carbohydrates of the broken rice were the most important constituents of these byproducts. As for the extruded product, all treatments produced the same viscosity profile in the broken rice flour, with no initial cold peak viscosity. The variation in the amount of barley bagasse flour and water in the formulation produced extruded flours with different rheological properties and pasting temperatures between 40 and $67^{\circ} \mathrm{C}$, maximum peak viscosity of 680 to $1146 \mathrm{cP}$, breakdown viscosity between 0 and $175 \mathrm{cP}$ and tendency of retrogradation between 401 and $1382 \mathrm{cP}$, values lower than for broken rice flour. The different barley bagasse flours and broken rice flours prepared by extrusion showed similar water adsorption properties. The isotherms showed a type II sigmoidal shape. The Peleg's mathematical model provided the best adsorption isotherms and can be used to estimate the equilibrium moisture content of an extruded mix of barley bagasse and broken rice flour. 


\section{Acknowledgements}

The authors appreciate the scholarship granted by the Researcher Program of the State University of Goiás (BIP) and by the Institutional Scholarship Program for Scientific Initiation by CNPq (PIBIC), as well as the financial supported granted by the Research Foundation of the State of Goiás (FAPEG) and by Embrapa Food Technology.

\section{References}

AL-MUHTASEB, A. H.; MCMINN, W. A. M.; MAGEE, T. R. A. Water sorption isotherms of starch powders. Part 1: mathematical description of experimental data. Journal of Food Engineering, Weinheim, v. 61, n. 3, p. 297-307, 2004.

ASSOCIATION OF OFFICIAL ANALYTICAL CHEMISTS - AOAC. Official methods of analysis of the Association of the Official Analysis Chemists. 18 ed. Arlington: Association of Analytical Communities, 2005. $1141 \mathrm{p}$.

ASCHERI, D. P. R.; ANDRADE, C. R.; CARVALHO, C. W. P.; ASCHERI, J. L. R. Obtenção de farinhas mistas pré-gelatinizadas a partir de arroz e bagaço de jabuticaba: efeito das variáveis de extrusão nas propriedades de pasta. Boletim do Centro de Pesquisa e Processamento de Alimentos, Curitiba, v. 24, n. 1, p. 115-144, $2006 \mathrm{a}$.

ASCHERI, D. P. R.; ANDRADE, C. T.; CARVALHO, C. W. P.; ASCHERI, J. L. R. Efeito da extrusão sobre a adsorção de água de farinhas mistas pré-gelatinizadas de arroz e bagaço de jabuticaba. Ciência e Tecnologia Alimentos, Campinas, v. 26, n. 2, p. 325-335, 2006b.

ASCHERI, D. P. R.; MOURA, W. S.; ASCHERI, J. L. R.; FREITAS JUNIOR, E. A. Propriedades termodinâmicas de adsorção de água do amido de rizomas do lírio-dobrejo (Hedychium coronarium). Ciência e Tecnologia de Alimentos, Campinas, v. 29, n. 2, p. 454-462, 2009.

ASCHERI, D. P. R.; NASCIMENTO, G. C.; ASCHERI, J. L. R. Características de adsorción de agua de la harina de arroz soluble a varias temperaturas. Alimentaria, Madrid, v. 40, n. 349, p. 111-119, 2003.

ASCHERI, D. P. R.; PEREIRA, L. D.; BASSINELLO, P. Z.; CARVALHO, C. W. P.; ASCHERI, J. L. R. Calidad del arroz de tierras altas en función del tiempo de cocción y del cultivar de arroz. Scientia Agraria, Curitiba, v. 11, n. 2, p. 163-173, 2010.

ASCHERI, D. P. R.; SOUSA, A. M. G.; CARVALHO, C. W. P. Curvas de secado y de isotermas de adsorción de agua de bagazo de cebada. Alimentaria, Madrid, n. 366, p. 102-115, 2005.

BUTOLO, J. E. Qualidade de ingredientes na alimentação animal. 2. ed. Campinas: Colégio Brasileiro de Alimentação Animal, 2002. 430 p.

CARDOSO, F. F.; ASCHERI, D. P. R.; CARVALHO, C. W. P. Propiedades reológicas y de adsorción de agua de harina extrudida de arroz y bagazo de cebada. Revista Ceres, Viçosa, MG, v. 61, n. 3, p. 313-322, 2014.

CEREDA, M. P.; DAIUTO, E. R.; VILPOUX, O. Metodologia de determinação de amido por digestão ácida em microondas. Revista $A B A M$, São Paulo, v. 2, n. 8, p. 1-29, 2004. Disponível em: <http://www.abam. com.br/revista/revista8/metodologia.php $>$. Acesso em: 20 nov. 2014.

CHIRIFE, J.; IGLESIAS, H. A. Equations for fitting water sorption isotherms of foods: Part 1 - a review. Internacional Journal of Food Science \& Technology, London, v. 13, n. 3, p. 159-174, 1978.

ELIAN, S. N. Análise de regressão. São Paulo: Instituto de Matemática e Estatística, 1988. 232 p.

FERNANDES, M. S.; WANG, S. H.; ASCHERI, J. L. R.; OLIVEIRA, M. F.; COSTA, S. S. J. Produtos extrusados expandidos de misturas de canjiquinha e soja para uso como petiscos. Pesquisa Agropecuária Brasileira, Brasília, v. 37, n. 10, p. 1495-1501, 2002.

FERREIRA NETO, C. J.; FIGUEIREDO, R. M. F.; QUEIROZ, A. Avaliação sensorial e da atividade de água em farinhas de mandioca temperadas. Ciência e Agrotecnologia, Lavras, v. 29, n. 4, p. 795-802, 2005.

FERREIRA, G. M.; QUEIROZ, A. J. M.; CONCEIÇÃO, R. S.; GASPARETTO, C. A. Efeito da temperatura no comportamento reológico das polpas de caju e goiaba. Revista Ciências Exatas e Naturais, Guarapuava, v. 4, n. 2, p. 175-184, 2002.

GENEROSO, R. A. R.; GOMES, P. C.; ROSTAGNO, H. S.; ALBINO, L. F. T.; BARRETO, S. L, T.; BRUMANO, G. Composição química e energética de alguns alimentos para frangos de corte em duas idades. Revista Brasileira de Zootecnia, Viçosa, v. 37, n. 7, p. 1251-1256, 2008.

GONZÁLEZ, R. J.; LIVORE, A.; PONS, B. Physicochemical and cooking characteristics of some rice varieties. Brazilian Archives of Biology and Technology, Curitiba, v. 47, n. 1, p. 71-76, 2004.

GOULA, A. M.; KARAPANTSIOS, T. D.; ACHILIAS, D. S.; ADAMOPOULOS, K. G. Water sorption isotherms and glass transition temperature of spray dried tomato pulp. Journal of Food Engineering, Weinheim, v. 85, n. 1, p. 73-83, 2008. 
GUY, R. Raw materials for extrusion cooking. In: Extrusion cooking. Boca Raton: Woodhead Publishing, 2001. cap. 2, p. 5-28.

INSTITUTO BRASILEIRO DE GEOGRAFIA E ESTATÍSTICA - IBGE. Estimativas de população. Rio de Janeiro: IBGE, 2014. Disponível em: <http://www. ibge.gov.br/home/estatistica/populacao/estimativa2012/ estimativa_tcu.shtm>. Acesso em: 16 nov. 2014.

INTERNATIONAL UNION OF PURE AND APPLIED OF CHEMISTRY. Reporting physisorption data for gas/ solid systems. Pure and Applied Chemistry, New York, v. 57, n. 4, p. 603-619, 1985.

JONGSUTJARITTAM, O; CHAROENREIN, S. The effect of moisture content on physicochemical properties of extruded waxy and non-waxy rice flour. Carbohydrate Polymers, Oxford, v. 114, p. 133-140, 2014.

JUNQUEIRA, O. M.; DUARTE, K. F.; CANCHERINI, L. C.; ARAÚJO, L. F.; OLIVEIRA, M. C.; GARCIA, E. A. Composição química, valores de energia metabolizável e aminoácidos digestíveis de subprodutos do arroz para frangos de corte. Ciência Rural, Santa Maria, v. 39, n. 8, p. 2497-2503, 2009.

KULCHAN, R.; BOONSUPTHIP, W.; SUPPAKUL, P. Shelf life prediction of packaged cassava-flour-based baked product by using empirical models and activation energy for water vapor permeability of polyolefin films. Journal of Food Engineering, Weinheim, v. 100, n. 3, p. 461-467, 2010.

LABUZA, T. P.; KAANANE, A.; CHEN, J. Y. Effect of temperature on the moisture sorption isotherm and water activity shift of two dehydrated food. Journal Food Science, Chicago, v. 50, n. 2, p. 392-396, 1985.

LIMA, C. H. A. M.; ASCHERI, D. P. R.; BASTOS, S. M. C. Características de adsorção de água de farinhas cruas e pré-gelatinizadas de duas variedades de arroz de terras altas. Boletim do Centro de Pesquisa de Processamento de Alimentos, Curitiba, v. 30, n. 1, p. 91-102, 2012.

LOMAURO, C. J.; BAKSHI, A. S.; LABUZA, T. P. Evaluation of food moisture sorption isotherm equations. Parte 1: fruit vegetable and meat products. $L W T-$ Food Science and Technology, Zurich, v. 18, n. 2, p. 111-117, 1985.

MARTI, A.; CARAMANICO, R.; BOTTEGA, G.; PAGANI, M.A. Cooking behavior of rice pasta: effect of thermal treatments and extrusion conditions. LWTFood Science and Technology, Zurich, v. 54, n. 1, p. 229$235,2013$.

MARTINEZ, C.; CUEVAS, F. Evaluación de la calidad culinaria y molinera del arroz: guía de estudio para ser usada como complemento de la unidad auditutorial sobre el mismo tema. 3. ed. Cali: Centro Internacional de Agricultura Tropical, 1989. 73 p.

NOOSUK, P.; HILL, S. E.; PRADIPASENA, P.; MITCHEL, J. R. Structure-viscosity relationships for thai rice starches. Starch/Stärke, Weinheim, v. 55, n. 8, p. 337-344, 2003.

OLIVEIRA, V. S.; AFONSO, M. R. A.; COSTA, J. M. C. Caracterização físico-química e comportamento higroscópico de sapoti liofilizado. Revista Ciência Agronômica, Fortaleza, v. 42, n. 2, p. 342-348, 2011.

PELEG, M. Assessment of a semi-empirical four parameter general model for sigmoid moisture sorption isotherms. Journal of Food Processing Engineering, Connecticut, v. 16, n. 1, p. 21-37, 1993.

PINKROVÁ, J.; HUBÁČKOVÁ, B.; KADLEC, P.; PŘÍHODA, J.; BUBNÍK Z. Changes of starch during microwave treatment of rice. Czech Journal of Food Science, Czech Republic, v. 21, n. 5, p. 176-184, 2003.

ROSTAGNO, H. S.; ALBINO, L. F. T.; DONZELE, J. L.; GOMES, P. C.; OLIVEIRA, R. F.; LOPES, D. C.; FERREIRA, A. S.; BARRETO, S. L. T. Composição de alimentos e exigências nutricionais de aves e suínos. Tabelas Brasileiras. 2. ed. Viçosa: UFV, 2005. 186 p.

SACCHETTI, G.; PINNAVAIA, G. G.; GUIDOLIN, E.; DALLA ROSA, M. Effects of extrusion temperature and feed composition on the functional, physical and sensory properties of chestnut and rice flour-based snack-like products. Food Research International, Amsterdam, v. 37, n. 5, p. 527-534, 2004.

SANTOS, A. P.; ASCHERI, J. L. R.; ASCHERI, D. P. R. Harina de bagazo de cebada y su incorporación en bizcochos. Alimentaria, Madrid, n. 393, p. 95-101, 2008.

SANTOS, D. M.; BUKZEM, A. L.; COUTINHO, N. D.; ASCHERI, J. L. R.; ASCHERI, D. P. R. Principais considerações da extrusão termoplástica de alimentos. Revista Processos Químicos, Anápolis, v. 8, p. 38-44, 2010 .

SARANTOPOUlOS, C. I. G. L.; OLIVEIRA, E. C. Requisitos de conservação de alimentos em embalagens flexíveis. Campinas: CETEA/ITAL, 2001. 215 p.

SILVA, R. F.; ASCHERI, J. L. R. Extrusão de quirera de arroz para uso como ingrediente alimentar. Brazilian Journal of Food Technology, Campinas, v. 12, n. 3, p. 190-199, 2009.

SOUZA, L. B.; LEONEL, M. Efeito da concentração de fibra e parâmetros operacionais de extrusão sobre as propriedades de pasta de misturas de fécula de mandioca e polpa cítrica. Ciência e Tecnologia de Alimentos, Campinas, v. 30, n. 3, p. 686-692, 2010. 
TIMMERMANN, E. O.; CHIRIFE, J.; IGLESIAS, H. A. Water sorption isotherms of foods and foodstuffs: BET or GAB parameters? Journal of Food Engineering, Weinheim, v. 48, n. 1, p. 19-31, 2001.

VAN DE KAMER, J. H.; VAN GINKEL, L. Rapid determination of crude fiber in cereals. Cereal Chemistry, Saint Paul, v. 29, n. 4, p. 239-251, 1952.

VIEIRA, A. A.; BRAZ, J. M. Bagaço de cevada na alimentação animal. Revista Eletrônica Nutritime, Viçosa, MG, v. 6, n. 3, p. 973-979, 2009.

WANDEE, Y.; UTTAPAP, D.; PUNCHA-ARNON, S.; PUTTANLEK, C.; RUNGSARDTHONG, V.;
WETPRASIT, N. Enrichment of rice noodles with fiberrich fractions derived from cassava pulp and pomelo peel. International Journal of Food Science \& Technology, London, v. 49, n. 11, p. 2348-2355, 2014.

WŁODARCZYK-STASIAK, M.; JAMROZ, J. Analysis of sorption properties of starch-protein extrudates with the use of water vapour. Journal of Food Engineering, Weinheim, v. 85, n. 4, p. 580-589, 2008.

ZHOU, Z.; ROBARDS, K.; HELLIWELL, S.; BLANCHARD, C. Composition and functional properties of rice. International Journal of Food Science and Technology, London, v. 37, n. 8, p. 849-868, 2002. 